\title{
Digital technology as a trigger for learning promises and realities
}

\author{
Juana M. Sancho-Gil \\ jmsancho@ub.edu \\ University of Barcelona, Spain
}

\begin{abstract}
In the last fifty years, the remarkable development of digital technology, that has permeated practically all social, economic, and cultural, political, and technological realms is producing several phenomena that have a direct impact in education. In this paper, I discuss first, the fact that more and more we refer to digital technology as just 'technology", as if the rest of the many organizational, symbolic, artefactual, and biotechnological developments were something "natural". Second, I refer to the rise and spread of technological solutionism in education and a growing discourse that sees every new digital technology as the arrival of the Promised Land, as the panacea to solve the problems of education. I go on analysing the collateral effects of this discourse in the educational practice, with an especial reference to persuasive technologies and Big Data. The article concludes with the request and the need for researchers, practitioners, and education policy makers to avoid the temptation to solve a deeply "wicked" problem such as education with simple solutions.
\end{abstract}

\section{Keywords}

Educational Technologies; technological solutionism; critical technology; persuasive technology. 


\section{Introduction: the endless transformation}

It is not the first time I am referring to topics covered in this article. And probably I will be on dealing with them over and over again. As researcher and educator, with Gramsci, I believe that the main aim of education is to promote men and women's development to move with their time. For this motive, I have repeatedly argued the importance of participating -and not only blindly accepting- in the configuration of our time and continually rethinking the role of every living entity and their environment in its possible scenarios (Sancho, 1995, 2004a, 2006, 2020, 2018, 2019a, 2019b; Sancho-Gil et al., 2019).

Other reasons for dealing with these issues in my research agenda lie, on the one hand, on the conviction that, as argued by Socrates, essential matters must be reminded again and again. And, on the other, on the vision that

Technology is not a thing in the ordinary sense of the term, but an "ambivalent" process of development suspended between different possibilities. This "ambivalence" of technology is distinguished from neutrality by the role it attributes to social values in the design, and not merely the use, of technical systems. On this view, technology is not a destiny but a scene of struggle. It is a social battlefield, or perhaps a better metaphor would be a parliament of things on which civilizational alternatives are debated and decided (Feenberg, 1991, p. 14).

From this perspective, for life in this planet, and even more important for education, "in choosing our technology we become what we are, which in turn shapes our future choices" (Ibidem, p. 14). Specially if we consider that the field of education has always been highly dependent on technological systems developed in other fields (Cuban, 1986; Noble, 1991; Zajda, 2015).

Life evolution, but also war and destruction, cannot be understood without technological development. The entanglement of artefacts, symbols (writing, numerical, digital systems, maps, icons, money, etc.), organizational techniques (Taylorism, Fordism, Toyotism, etc.) and biotechnologies (from agriculture to genetic modification) have been profoundly affecting, for good and bad, nature, nurture, and cultures, living creatures and matter.

have been profoundly affecting, for good and the bad, nature, nurture, and cultures, living creatures and matter.

The history of technological developments shows how the widespread use of different artefacts and techniques has an often-unforeseen impact on the very organisation of society and the way we perceive the world, creating new realities (Mumdford, 1938; Shallis,1986). For instance, according to Mumford, the clock disassociated time from human events, helping to believe in an independent world of mathematically measurable sequences. The abstract framework of divided time became a reference point for action and thought. Or increasingly efficient and individualised transport systems (especially cars) profoundly transformed cities while making them increasingly unsustainable.

In the last fifty years, the impressive -and for many people, the unstoppable explosion of information and communication technologies has profoundly transformed all social, economic and cultural, political and technological realms practically, producing several phenomena that have a direct impact in education. In this paper I discuss, first, how talking more and more about merely "technology" to refer to digital technology, as if all the other many organisational, symbolic, artefactual and biotechnological developments were something "natural", is producing an oversimplification of what we mean by education and its challenges. Second, I discuss the rise and spread of technological solutionism (Morozov, 2013) in education and a growing discourse that sees every new digital technology as the arrival of the Promised Land, as the panacea to solve the problems of education. I go on analysing the collateral effects of this discourse in the educational practice, with an especial reference to persuasive technologies (Fogg, 2003) and Big Data 
(Williamson, 2017). The paper concludes with the request and the need for researchers, practitioners, and education policymakers to avoid the temptation to solve a deeply "wicked" problem (Rittel \& Webber, 1984) such as education with simple solutions.

\section{Narrowing the scope of technology. Implications for education}

The most profound technologies are those that disappear. They weave themselves into the fabric of everyday life until they are indistinguishable from it (Weiser 1991, p. 94).

Recently, I have again referred to the need of questioning the dominant reductionist view of technology underling most digital technology-driven discourses and initiatives (Sancho-Gil, et al., 2019). Considering decolonial perspectives (Abdi, 2012; Canella \& Viruru, 2004; Castro-Gómez \& Grosfoguel, 2007; De Sousa, 2010; Young, 2001), the inclination to overlapping the term "technology" with digital applications looks rather colonialist. It seems to ignore most accumulated knowledge developed over time by different people in different parts of the world, and be based on an "ahistorical and decontextualized approach [that] systematically disregards the whole history of humanity, civilisation and the continuous development of systematic techniques for making and doing things" (Sancho-Gil et al., 2019, p. 2). It forgets that development and quality of life are deeply related to people's ability to maintain and improve the lives of all the inhabitants of the planet and that the creation of artefacts, symbols, organisational and biotechnological systems is as old as civilisation (Álvarez, Martínez \& Méndez, 1993).

The tendency to consider "technology" only to "new technologies" can be located in Western societies at the end of Second World War, promoted by idea of technology as applied scientific knowledge, deeply linked to the production of artefacts, innovation, consumerism and progress. This notion has speeded up since the development of 'digital technology' converting the owners of a few corporations into the most powerful and wealthy people in the world ${ }^{1}$. And Taking people to think schools are not using technology if they are not using screens, as if books, pencils, maps, labs, were something "natural" that has been always there. Recently a journalist asked to a British Government adviser on education issues, if "technology can replace textbooks" and the advisor to answer, "if all we do is exchange books for technology and use it in the same way, it's just another way of making the same mistake" (Álvarez 2017, n.p.). Maybe for him, a book is not a technology of information.

This drift, as argued by Heidegger (1977, p. 4), leads to the loss of the meaning of technology for humanity and its significance for most human beings.

The essence of technology is by no means anything technological. Thus, we shall never experience our relationship with the essence of technology, so long as we merely conceive and push forward the technological, put up with it, or evade it. Everywhere, we remain unfree and chained to technology whether we passionately affirm or deny it. However, we are given over to technology when we regard it as something neutral; this conception, to which today we particularly like to pay homage, makes us utterly blind to the essence of technology.

\footnotetext{
11 Jeff Bezos, Amazon; Bill Gates, Microsoft; Mark Zuckerberg, Facebook; Larry Ellison, Oracle; Larry Page, Google; Carlos Slim, America Movil; Sergey Brin, Google are among the 11 richest men in the world.
} 
However, the most severe impact on education of overlapping of "technology" (meaning digital technology) and "educational technology" is to miss out all the complexity of education and educational systems. Is implying that education only consists of information transmission. Is disregarding that educational systems, in terms of Foucault (1980, p, 194-5) are highly powerful dispositifs, understood as:

a thoroughly heterogeneous ensemble consisting of discourses, institutions, architectural forms, regulatory decisions, laws, administrative measures, scientific statements, philosophical, moral, and philanthropic propositions [...]. Such are the elements of apparatus [dispositif]. The apparatus itself is a system of relations that can be established between these elements. [...] a particular discourse can figure at one time as the programme of an institution, and at another it can function as a means of justifying or masking a practice which itself remains silent, or as a secondary re-interpretation of this practice, opening out for it a new field of rationality. [...] The apparatus [dispositif] has a dominant strategic function.

They are human constructions made up of artefactual, organizational, symbolic technology and even biotechnology built on power relations. While for Mecklenburgers (1990, p. 106) school, the most spread organisational ad symbolic metaphor of formal education, "is a 'technology' of education, in the same way as cars are a 'technology' of transportation".

But above all, education is one of the best exemplifications of what Rittel \& Webber (1984, p. 136) coined, for social system design, as "wicked" problems. For these authors, "wicked" problems are those poorly formulated. The information needed to understand them depends on the ideas of those trying to solve them. Require a comprehensive inventory of all possible solutions previously proposed. It is practically impossible to understand the problem without knowing its context, nor to search for information without looking at the possible solution. They are not considered solved for reasons inherent to the logic of the problem (true-false), but because of what those who try to solve them find an adequate degree of "satisfaction". Any intervention in a "wicked" problem has consequences, leaving traces that cannot be erased by a "reparative" action of its unwanted effects, which in turn will generate other problems. They have specific characteristics that make them "unique" and act as symptoms of other issues (Buchanan, 1992; Rittel \& Webber, 1984).

Can we think of a more "wicked" problem than education? If this is the case, can we believe that an out-of-context digital technology could be the solution to these types of problems?

In the next sections, I discuss the origins, evolutions and consequences of narrowing down the challenges of education to simple technological solutionism in a hypercapitalist world (Graham, 2000).

\section{The rise and spread of technological solutionism}

For every complex problem there is an answer that is clear, simple, and wrong. (H. L. Mencken, 1880-1956)

Recently, authors such as Morozov (2013) have started challenging the so-called "folly of technological solutionism". Technological solutionist claim that life will improve dramatically, for everybody, once digital technology makes more decisions for us, makes it easier to track and analyse behaviour, dismantles long-standing hierarchies, and erodes barriers to the flow of communication. He adds "solutionism" to the list of errors that spoil discussions about the role of technology in politics, crime reduction, privacy, and behaviour modification. Solutionism, results 
from disregarding the characteristics of "wicked" problems, by 'inventing' a problem, misrepresenting this fiction as a genuine and urgent dilemma and advocating the use of digital technology to fix it.

In the field of education, we can identify the starting point of this phenomenon in the United States around 1900 with the beginning of Science and Technology of Education (Saettler, 1990). This author connects the emergence of this field with Thorndike, Dewey, Kilpatrick, Montessori, etc., and with the educational film movement. However, he recognizes as its forerunners the authors we find in any history of education, Pedagogy, Didactics, and Educational Psychology (Berliner, 1992), from the sophists and the Socratic method, to Comenius, Lancaster, Pestalozzi, Froebel, and Herbart.

According to Saettler (1990), Educational Technology, as a field of study and as an academic discipline, takes shape in the United States of America, mainly from the 1940s onwards. The first specific reference does not appear in the field of education, but the courses designed for military specialists supported by audio-visual instruments, given during the Second World War. Thus, it seems crucial to take into account that the development of most devices and systems used in formal education -from the overhead projector to computers and the Internet, had its origin in the war industry (Noble, 1991) and the instructional design, envisioned as a scientific way of planning teaching, was were developed in the training of soldiers.

From now on, the commercialization of any new information technology has given rise to inflated statements about the incredible power of any new device to solve educational problems. Cuban (1986) provides an overall account of the expectations generated around the film, radio, television, and computer industries. In 1913, Thomas Edison was convinced that "books will be soon obsolete in the schools [..] scholars will soon be instructed through the eye. It is possible to touch every branch of human knowledge with the motion picture" (p. 11). In 1932, Darrow, converted the Radio in The Assistant Teacher,

the central and dominant aim of education by radio is to bring the world to the classroom, to make universally available the services of the finest teachers, the inspiration of the greatest leaders, and unfolding world events which through the radio may come as a vibrant and challenging book of the air (p. 19).

The rise of television also captured the imagination of technology devotees. Since its regular broadcastings in 1929 in Great Britain, a considerable set of initiatives were launched to convert it into a permanent learning tool. Seymour Papert was convinced that "in the future there will be no schools... I think the computer will blow them up" (p. 72).

With the development of multimedia systems, authors such as Lamb (1992) asserted that all educational resources created in the last two centuries, from textbooks to blackboards, overhead projectors, videos, and computers were now coming together in a single interactive workstation. Schools will become interactive workstations that will allow teachers to consider students' cognitive styles. While Franklin and Kinnell (1990) assured that hypermedia and hypertext programs will improve students' access to knowledge, reveal ideas in teachable moments, show connections among different subjects, foster integrative thinking and act as powerful representation tools. And Lajoie (1993) conceptualised computers as cognitive tools being able to: (a) support cognitive processes such as memory and meta-cognition; (b) share the cognitive load by helping with the low-level cognitive tasks to allow intellectual resources to be used for higher-order thinking processes; (c) enable students to perform cognitive activities to which they would not have access in another way; (d) permit students to generate and test hypotheses.

In 1995, Bill Gates, Myhrvold and Rinearson gave the "highway" (Internet) all sorts of powers and benefits for education: providing access to unlimited information to everyone at any time and in any place; discovering all kinds of teaching approaches, the use of different methods and the 
measuring their effectiveness; keeping a cumulative record of a student's work, which can be reviewed at any time or shared with other teachers; help summarize information about students' skills, progress, interests and expectations; review and easily discuss the particulars of student progress; address learning problems; allow each student to work at his or her own pace; allow students to question themselves at any time, in a safe environment; examine themselves will become a positive part of the learning process. The failure of Bill Gates' programme to improve education is well known (Strauss, 2018), as is also known the fiasco of Chan and Zuckerberg Foundation's personalized learning software (Hedman, 2019; Kronk, 2018). However, it is crucial to point out that everything related to recording student and teacher activity has begun to be used by corporations to increase their persuasion techniques (Fogg, 2003).

With the unstoppable development of digital technology and its wide use in all layers of society, many scholars and educational systems seem to be convinced that:

- ICT can increase authenticity and interest.

- ICT can build virtual communities among different schools, collaborating teams, and teachers.

- ICT can help to share perspectives among students with different expertise. proving peer support and "benchmarking practices" in different fields.

- ICT facilitates the use of technology-supported inquiry approaches and problem-based models for increasing learning-to-learn skills.

- ICT provides innovative ways (for example, mobile tools) of integrating "just-in-time" support and interaction in different learning contexts (Järvelä, 2006, p. 40).

This enthusiasm persists in our days, despite the stubborn educational reality, which continues to present chronic problems of lack of investment and difficulties in sustaining student interest. Situation that, once again, some analyse from the technological solutionism perspective (Neelakantan, 2019).

Since the very beginning, large media consortia made notable efforts for seeing, first, the information they broadcasted, including publicity, in schools and classrooms. Then, making sure educational systems bought their products. And finally, by more and more directly involved in educational systems. They very soon understood the economic potential of educational systems as direct clients and as consumer suppliers. In 1972, one of the first projects to introduce computers into the curriculum was carried out in England (Development Programme in Computer Assisted Learning). An independent evaluation was requested from CARE (Centre for Applied Research in Education), coordinated by Barry MacDonald (1977) from a democratic perspective. What the review revealed was that schools had no immediate need to introduce computers and that their use had not improved any of the teaching practices in which they were used. But those who had benefited from the project were the computer companies because it had been an incredibly effective way of selling their products, at a time when it was difficult to sell computers. After all, in 1972 few people were willing and able to buy one.

\section{Collateral effects}

At this moment, for an impressive amount of people, digital technology has become a fundamental part of the life's substratum. Many of them, especially the young ones, think impossible to survive without an iPhone and Internet connection (Tweenge, 2017). And probably the whole society would have a difficult time if the electricity went off and the multiple digital systems that govern society 
were disconnected. In this context, the amount of time spent in front of screens is having significant consequences for people's cognitive, social, mental, and physical development (Alter, 2017; Carr, 2010). All that has considerable effects on education, if we think of education not as a mere transmission of information, but as the process of accompanying people in the development of their potentialities for responsibly contribute to the construction of a more fair, friendly, healthy and sustainable society.

The narrow focus of Educational Technology, which ignored all the complexity of educational systems and focused research on devices and applications, led to the need to study not only the "flute and the orchestra" (Salomon, 1990), but,

Following the musical metaphor, it would also entail the consideration of the auditorium's acoustics, the meaning musicians and directors give to their performance, their perceptions of how their performance was contributing to their personal and professional development, without, or course, forgetting the policy regarding Music. (Sancho, 2004a, p. 147).

At this time, given the enormous impact of digital technologies on people's lives virtually from birth $^{2}$, educators also need to pay attention to child and young people learning lives out of school (Erstad, 202; Livingstone and Sefton-Green, 2016). Something educational systems hardly consider (Sancho \& Alonso, 2012; Hernández-Hernández, 2017), regardless of the considerable changes in youth cultures, attitudes, and predisposition to learn.

As I have argued previously (Sancho, 2009; 2014), at the beginning of the $20^{\text {th }}$ century, in a context of technological euphoria, Howe \& Strauss (2000) called Millennials to generations born from the 1980s onwards, who grew up in a context where digital technologies were an inherent part of everyday life. Millennials were thought to be skilful with computers, creative with technology and, above all, highly proficient at multitasking in a world where ubiquitous connections are taken for granted.

In 2001, Marc Prensky called young people "digital natives" and, without considering that "natives" also have to learn the language, he argued that the problem with education was that teachers were "digital immigrants", who spoke an outdated language. In an explicit and euphoric way, young people were characterized as more intelligent, alert and even prepared. For example, Boschma \& Groe (2006) called them the "Einstein generation", considering them smarter, faster and with more social skills. However, in recent years this discourse seems to have begun to change. In 2008 Nicholas Carr wondered if Google was making us stupid. He said he was uncomfortable with the feeling that something or someone was playing with his brain, reassigning its neural circuits, and reprogramming its memory. He noticed that his mind was changing, especially when he read a book or a long article, which led him to wonder What the Internet Is Doing to Our Brains (Carr, 2010). On the other hand, worries about school engagement, results and young people's behaviour, have fostered research about the effects of digital technology-based practices in students learning capacity (Janssen, et al., 2015; Oliver, 2017; Uncapher et al., 2016).

In a world with apparently unlimited technology and information, one of the problems seems to be that everyone is seeking to attract individuals' attention. Without paying attention (which implies time), friendship, love, family, followers, business, work, and learning are impossible. Faced with the impossibility of attending to everything and everyone that calls our attention, as pointed out by Lankshear \& Knobel (2001) and Lanham (2006), in the new economy, the scarcest product is attention. Educational systems are the losers of this war for attention. Education has never had resources to develop and invest in the needed means to meet the changing challenges it must face. And once more, corporations are there with persuasive technologies, algorithms and "big data".

\footnotetext{
2 We are more and more use to seeing very young kids in front of a screen, while their parents or caretakes speak with friends in restaurants or are looking at their displays. A trend that has begun to raise concerns about the pernicious effect it may have on child development (Hutton, et al., 2020; Reichel, 2019).
} 


\section{a. Persuasive technologies}

Those who suffer from a hunger for power find in the mechanization of man a simple way to achieve their ambitions (Weiner, in Peirano, 2019, p. 13)

Francis Bacon, in his work New Atlantis (published in 1627), built the first utopia that considered technology as the primary trigger of development and welfare of humanity, prophesying a set of inventions. He described a city that was not progressing thanks to the refinement of socio-political forms, but technical advances. The most important characteristic of this utopic city was that they were not the metaphysicians who regulated the citizens' well-being through abstract doctrines established once and for all, as in the case of Plato's Republic. But the group of researchers who were always discovering new truths that could alter the conditions of life. Since then, Western history is full of satiric contradictions such as,

the scientists who developed the atomic bomb to save the world or the lobbies who defend the right to have weapons so that citizens can sleep soundly. The road to hell is paved with good intentions. Skinner wanted to manipulate the masses to save them, which is the same thing that Google, Apple, Facebook, Amazon, or Microsoft have set out to do. [...] Fogg wanted to systematize our habits so that we would exercise more, eat fewer doughnuts, and stop smoking. The truth is his good intentions are as irrelevant as his political leanings. The goal of his algorithm is to manipulate the human mind to feel and need things it did not need or think for itself (Peirano, 2019, p. 53-54).

Building up Skinner ideas, in 1998 B. J. Fogg created at Stanford University the Persuasive Technology Lab, focused in designing machines to change what people think and do, and do it automatically, to foster a healthy behaviour change. He was convinced that interactive applications could be designed using the social engineering tactics and interactive design techniques of computer engineering to which he added "captology", the science of using computers as persuasion technologies. "He talked about helping people stay fit, quit smoking, manage their finances and study for exams. Two decades later, his methods are world-famous for generating billions of dollars for several dozen companies, but not for helping anyone quit" (Peirano, 2019, p. 28).

The Fogg Behavioural Model, in fact, is well known in the field of education. Although systematically, for obvious reasons, is being used much more successfully in industry than in education. The three principal factors of the model are motivation, ability, and triggers. That is to say, for a behaviour to occur, a person must have sufficient motivation, sufficient capacity, and an active trigger. All three factors must be present at the same moment to foster the produced behaviour; if one of the three is missing, the objective cannot be achieved (Fogg, 2009). It is why most parents and teachers know the difficulty of "persuading" children and youth. However, digital corporations are having a much comfortable and productive time.

The successful implementation of Fogg's model in digital corporations seems to be based in their ability to use three main proposed motivators: 1) pleasure / pain; 2) hope / fear; 3) social acceptance / rejection. This last motivation is one of the most considered by digital platforms and applications and helps to understand the amazing success of social networking services. But also, the increase of syndromes such as the so-called FOMO (Fearar of Missing Out) "defined as a pervasive apprehension that others might behaving rewarding experiences from which one is absent" and "characterized by the desire to stay continually connected with what others are doing" (Przybylski, 203, p. 1841). FOMO perpetuates especially young people's fear of having made the wrong decision on how to spend time since they can imagine how things could be different. 
Persuasive technologies are developed by corporations through platforms and applications based on what Peirano (2019, p. 34) calls "DARK DESIGN: CLAIM, SCORE, LEVER, REPEAT". Successful Skinner's behaviourism at the digital age, is being highly effective in putting things into users' heads that were not there before. Companies such as Boundless Minds ${ }^{3}$ (formerly Dopamine Labs), which motto is "Predictably Change Your Users' Behavior with AI", use persuasive technologies and neurohacking (Sawant, n.d.) for shaping human behaviour. The end of this company is to promoting change for the better so that the entire society can become more neuro-literate.

The big project that my team and I have been working on for the past few years that we've released as our core service is an artificial intelligence system that any app and any technology can plug into to find those perfect moments of surprise and delight. [...] You don't have to bribe them with a Porsche. You don't have to give them a promotion. Just these little hits of dopamine (Dooley, 2018, para. 6).

But in the end, the primary purpose of companies is to sell their products and make sure users give constant information about themselves and devote all their time and attention to their applications. As researchers and educators, we need to understand the positive and negative consequences of these trends for students. In general, the positive is much more publicized. But, in the last years, more attention is being paid to its pernicious effects, such as the dispersion of students' attention, the reliability of the information they access and the addictive behaviours (Alter, 2017). According to a recent survey of 4,000 young people, in Spain, $21 \%$ of young people between the ages of 10 and 25 suffer from behavioural disorders because of technology. Because of this worrying figure, this kind of addiction will be included in the new National Plan on Drugs of the Ministry of Health (Torres, 2019).

Several countries have banned the use of iPhone in schools. Apparently, the promoters and principal beneficiaries of these technological applications themselves, try to preserve their children from their influence and take them to schools where there is little or no use of digital devices (Lahitou, 2018; Weller, 2018). However, these big corporations, through their "free" ${ }^{4}$ platforms and services, are permeating educational systems more and more. Teachers and students provide them with an amazing amount of data (Big Data) they convert into algorithms that shape students learning.

\section{b. Big Data}

First they said they needed data/about the children/to find out what they're learning. /Then they said they needed data/about the children/to make sure they are learning. /Then the children only learnt/what could be turned into data. / Then the children became data. (Michael Rosen, 2018 ${ }^{5}$ )

As we have seen recently, due to the role of Cambridge Analytica in Trump's elections (The Guardian, n.d.a; n.d.b), digital corporations are more and more using all kind of data, especially those of their users, to convert them into algorithms to make important decisions across society (Cheng et al., 2019) or influence users' behaviour. And of course, education does not escape this trend (Williamson, 2017).

\footnotetext{
${ }^{3}$ https://www.boundless.ai/

${ }^{4}$ Maybe we should not forget Henry David Thoreau thought, in his utopia Walden (Life in the Woods), written in 1854: "The cost of a thing is the amount of what I will call life which is required to be exchanged for it, immediately or in the long run."

${ }^{5}$ http://michaelrosenblog.blogspot.com/2018/02/the-data-have-landed.html
} 
Rachel Buchanan and Amy McPherson (2019) argue that the frenetic data collection activity taking place in many countries around the world in schools is transforming education. For them,

Australia may be heading towards an educational future designed by Silicon Valley not by educators and school communities. The developers of educational technologies have a growing influence in our classrooms, and we are witnessing a shift of public education from a democratic controlled system to one designed and run by corporations (para. 2)

This applies many other countries where students' educational progression from preschool to further and higher education can be tracked, along with many other activities such as physical activity, use of digital devices, social media, etc., etc. To all this information must be added data provided by students and teachers through learning platforms and personalised learning apps used classrooms or at home (Thompson, 2017), all of them designed with persuasive technologies driven by algorithms based on student data to foster progression and motivation as well as surveillance (Warzel, 2019).

Buchanan and McPherson (2019) argue that at this moment "the nature of teachers' work is being changed by data." That educational systems are being reconfigured by data-based technologies, built on behaviourist theories, not only oriented to change learner's behaviour but to collect data students' emotional, psychological, and cognitive and neurological states (Williamson, 2017). They are convinced than school students located in different parts of the world, can be learning from the same apps or techno-education programs. "These Silicon Valley technologies would determine what, when, and how students learn - with curriculum and assessment determined algorithmically based on students' prior engagement and achievement." For them, replacing of teacher expertise with the pattern detection abilities of data analytics algorithms (Lupton \& Williamson, 2017), can reduce students' opportunities by the assumptions encoded in algorithmic logic.

However, education, as they also discuss, cannot only be reduced to learning information and dealing with data. Education is about building the kind of civilisation we want to overcome today's problems, many of them due to the narrowness of technological developments and the greed and power/wealth-seeking of some people. Developing a better educational system and a better world needs much more than Artificial Intelligence. What is required is intelligence, empathy, affection, care, and honesty. and this, as in the system devised by Fogg, must be given at the same time. So, let us leave technological solutionism behind, let us focus on what's important, let's not be dazzled by virtual reality and the power of algorithms.

\section{Concluding remarks}

Today's education faces a significant number of challenges. It is no easy to educate young people in a continually changing world, when the educational system we know were developed to transmit the past, not to invent the future. Those responsible for educational policy and teaching practice, who also have difficulty themselves in understanding the contemporary world, must decide om educational systems and teach young people not only to understand today's society but to live in it in a responsible and not non-subordinate way. In this context, digital technologies are playing a significant role and it is clear students need to develop and acquire an emerging and complex set of knowledge and skills.

However, the solution to this "wicked" problem, cannot be only found in one of the essential sources of the problem itself. And even less so when companies with high power to run the world are not willing to lose it, nor to make their processes more transparent, nor to question the meaning of their development. All these questions should be known and considered in the field of education. But we need to careful rethink which role we want to give to digital technologies, and 
especially, decide the kind of knowledge and technologies needed to educate young people and ourselves.

\section{Acknowledgments}

ESBRINA Research group. Contemporary Subjectivities, Visualities and Learning Environments (2017SGR 1248). http://esbrina.eu

REUNI+D Network of excellence. University Network for Research and Educational Innovation EDU2015-68718-REDT. http://reunid.eu

\section{References}

Álvarez, A., Martínez, A., \& Méndez. R. (1993). Tecnología en acción. Barcelona: Rap.

Álvarez, P. (2017, October 4). Richard Gerver: Hay demasiadas modas pasajeras en la educación. El País. Retrieved from https://elpais.com/politica/2017/10/02/actualidad/1506943955_129970.html

Alter, A. (2017). Irresistible: The Rise of Addictive Technology and the Business of Keeping. New York: Penguin Press.

Berliner, D. C. (1992). Telling the Stories of Educational Psychology. Educational Psychologist, 27, 143-152.

Boschma, J., \& Groe, I. (2006). Generación Einstein: más listos, más rápidos y más sociales. Comunicarse con los jóvenes del siglo XXI. Retrieved from http://www.anele.org/jornadas_tecnicas/generatie_einsteinspaans_jeroen.pdf.

Buchanan, R. (1992). Wicked Problems in Design Thinking. Design Issues, 8(2), 5-21. doi: 10.2307/1511637

Buchanan, R., \& McPherson, A. (2019, July 8). Education shaped by big data and Silicon Valley. Is this what we want for Australia? EduResearch Matters, https://www.aare.edu.au/blog/?p=4182

Carr, N. (2008, July). Is Google Making Us Stupid? The Atlantic, 301 (6). Retrieved from http://www.theatlantic.com/magazine/archive/2008/07/is-google-making-usstupid/6868/

Carr, N. (2010). The Shallows: What the Internet Is Doing to Our Brains. New York/London: W. W. Norton \& Company.

Cheng, H. F., Wang, R., Zhang, Z., O'Connell, F., Gray, T., Harper, F. M., \& Zhu. H. (2019). Explaining Decision-Making Algorithms through UI: Strategies to Help Non-Expert Stakeholders. The 2019 CHI Conference. Glasgow, Scotland, UK. DOI: 10.1145/3290605.3300789

Cuban, L. (1986). Teachers and machines: The classroom use of technology since 1920. London: Teachers College Press.

Dooley, R. (2018, June 7). Persuasive AI with Ramsay Brown. Retrieved from https://www.rogerdooley.com/ramsay-brown-boundless/

Erstad, O. (2012). The Learning Lives of Digital Youth-Beyond the Formal and Informal. Oxford Review of Education, 38 (1), 25-43. doi:10.1080/03054985.2011.577940.

Fogg, B. J. (2003). Persuasive Technology: Using Computers to Change what We Think and Do. Amsterdam; Boston: Morgan Kaufmann Publishers.

Fogg, B. J. (2009). A Behavior Model for Persuasive Design. Persuasive'09, April 26-29. Claremont, CA. Retrieved from https://www.mebook.se/images/page_file/38/Fogg\%20Behavior\%20Model.pdf

Foucault, M. (1980). Power/Knowledge: Selected Interviews and Other Writings 1972-1977, ed. C. Gordon. New York: Pantheon.

Franklin, C., \& Kinnell, S.K. (1990). Hypertext/Hypermedia in Schools. A Resource Book. San Francisco, CA: ACB-CLIO.

Gates, B., Myhrvold, N., \& Rinearson, P. (1996). The road ahead. New York: Penguin Books.

Graham, P. (2000). Hypercapitalism: A Political Economy of Informational Idealism. New Media and Society 2(2), 131-56.

Heidegger, M. (1977. The Question Concerning Technology. New York: Harper Brooks.

Hedman, E. (2019, Apr 24). Why personalized learning keeps failing. Retrieved from https://uxdesign.cc/whypersonalized-learning-keeps-failing-3dc9b0fe4e0 
Hernández-Hernández, F. (ed.) iY luego dicen que la escuela pública no funciona! Investigar con los jóvenes sobre cómo transitan y aprenden dentro y fuera de los centros de Secundaria. Barcelona: Octaedro.

Hutton, J. S., Dudley J., Horowitz-Kraus T., DeWitt T., \& Holland S. K. (2020). Associations Between ScreenBased Media Use and Brain White Matter Integrity in Preschool-Aged Children. JAMA Pediatr., 174(1):e193869. Doi :https://doi.org/10.1001/jamapediatrics.2019.3869

Janssen, C. P., Gould, S. J. J., Li, S. Y. W., Brumby, D.R., \& Cox, A. L. (2015). Integrating knowledge of multitasking and interruptions across different perspectives and research methods. International Journal of Human-Computer Studies, 79 pp. 1-5. 10.1016/j.ijhcs.2015.03.002.

Järvelä, S. (2006). Personalised Learning? New Insights into Fostering Learning Capacity. In OECD/CERI (eds.), Personalising Education (pp. 31-46). Paris: OECD/CERI.

Kronk, H. (2018, July 09). Why Do So Many Parents Opt Out of Summit Learning? Retrieved from https://news.elearninginside.com/why-do-so-many-parents-opt-out-of-summit-learning/

Lahitou, J. (2018, Agust 18). Silicon Valley Parents Choose Low \& No Tech Schools. What About Your Kid's School? Recuperado de https://goodmenproject.com/uncategorized/silicon-valley-parents-choose-lowno-tech-schools-thats-probably-not-the-tech-policy-at-your-kids-school/

Livingstone, S., \& Sefton-Green, J. (2016). The Class: Living and Learning in the Digital age. New York: New York University Press.

Morozov, E. (2013). To save everything, click here: The folly of technological solutionism. New York: PublicAffairs.

Mumford, L. (1938). Technics and civilization. New York, Harcourt, Brace and Company.

Neelakantan, S. (2019). How K-12 Schools Can Use Technology to Combat Absenteeism. Ed Tech Magazine. https://edtechmagazine.com/k12/article/2019/12/how-k-12-schools-can-use-technology-combatabsenteeism?utm_source=IGI+Global+Products+and+Publishing+Opportunities\&utm_campaign=8edf 04c303-

EMAIL_CAMPAIGN_Research_Trends_1_19_wk1_COPY_01\&utm_medium=email\&utm_term=0_bcbd62 7034-8edf04c303-47654342

Noble, D. D. (1991). The Classroom Arsenal: Military research, Information Technology, and Public Education. The Falmer Press.

Lajoie, S. P. (1993). Computer Environments as Cognitive Tools for Enhancing Learing. In S. P. Lajoie \& S. J. Derry (eds.). Computers as Cognitive Tools. Hillsdale, NJ: Lawrence Erlbaum Assaociates, Pu.

MacDonald, B. (1977) The Educational Evaluation of NDPCAL. British Journal of Educational Technology, 8(3), 176-89.

Mecklenburgers, J. A. (1990). Educational Technology is not enough. Phi Delta Kappan 72 (2), 104-108.

Morozov, E. (2013). To save everything, click here: The folly of technological solutionism. New York: PublicAffairs.

Oliver, N. (2017). Erudit@s digitales. In S. Lluna and J. Pedreira (eds.). Los nativos digitales no existen. Cómo educar a tus hijos para un mundo digital (pp. 157 - 176). Barcelona: Deusto Ediciones

Peirano, M. (2019). El enemigo conoce el sistema. Manipulación de ideas, personas, influencias después de la economía de la atención. Barcelona: Debate.

Prensky, M. (2001). Digital Natives, Digital Immigrants. On the Horizon, 9 (5), 1-6. http://www.marcprensky.com/writing/Prensky\%20\%20Digital\%20Natives,\%20Digital\%20Immigrants\%20-\%20Part1.pdf

Przybylski, A. K., Murayama, K., De Haan, C. R., \& Gladwell, V. (2013). Motivational, emotional, and behavioral correlates of fear of missing out. Computers in Human Behavior, 29(4): 1841-1848. doi:10.1016/j.chb.2013.02.014.

Reichel, C. (2019). The health effects of screen time on children: A research roundup. Journalist's Resource. https://journalistsresource.org/studies/society/public-health/screen-time-children-health-research/

Rittel, H. W. J., \& Webber, M. M. (1984). Planning Problems are Wicked Problems. Developments. In N. Gross (ed.), Design Methodology (pp. 135-144). London: John Wiley and Sons.

Saettler, P. (1990). The Evolution of American Educational Technology. Englewood, CO: Libraries Unlimited, Inc.

Salomon, G. (1990). Studying the flute and the orchestra: controlled vs. classroom research on computers. International Journal of Educational Research, 14(6), 521-531. https://doi.org/10.1016/08830355(90)90022-Z

Sancho, J. M. (1995) ¿El medio es el mensaje o el mensaje es el medio? El caso de las Tecnologías de la Información y la Comunicación. PixelBIT Revista de Medios y Educación, 4, pp. 51-67.

Sancho, J. M. (2004a). What kind of technologies for what kind of education In R. Aviram and J, Richarson (eds.), Upon What Does the Turtle Stand Up? (pp. 159-176). Dordrecht: Kluwer. 
Sancho, J. M. (2004b). Virtual Geographies of Educational Change: The more complex the problems the simpler the answers. In Hernández, F., \& Goodson, I. (eds.), Social Geographies of Educational Change (pp. 143-167). Dordrecht: Kluwer.

Sancho, J. M. (2006) Evolving Landscapes for Education. In Zielindsky, Ch., Duquenoy, P., \& Kimppa, K. (eds.), The Information Society: Emerging Landscapes (pp. 81-100). EUA: Springer.

Sancho, J. M. (2010). Digital Technologies and Educational Change. In Hargreaves, A., Lieberman, A., Fullan, M., \& Hopkins, D, (eds.), Second International Handbook of Educational Change (pp. 433-444). Springer International Handbooks of Education. 978-90-481-2659-0.

Sancho, J. M. (2014). ¿Son más listos o más estúpidos? ¿Dónde está la educación? Hachetetepé, 9, 71-80.

Sancho, J. M. (2018). Sin educación no hay justicia social. En P. Rivera-Vargas, J. Muñoz-Saavedra. R. Morales-Olivares, S. Butendieck-Hijerra (Eds.), Políticas públicas para la equidad social (pp. 103-112). Santiago de Chile: Coleccion Politicas Publicas, Universidad de Santiago de Chile. DOI: https://doi.org/10.13140/RG.2.2.34994.50886/1

Sancho, J. M. (2019a). ¿En qué manos está la educación? El Diario de la Educación. https://eldiariodelaeducacion.com/blog/2019/10/21/en-que-manos-esta-la-educacion/

Sancho, J. M (2019b). De la tecnología para aplicar a la tecnología para pensar: implicaciones para la docencia y la investigación. RELATEC. Revista Latinoamericana de Tecnología Educativa, 18(1), 9 -22. https://doi.org/10.17398/1695-288X.18.1.9

Sancho J. M., \& Alonso, C. (2012). (eds.). La fugacidad de las políticas, la inercia de las prácticas. La educación y las tecnologías de la información y la comunicación. Barcelona: Octaedro.

Sancho-Gil, J. M., Rivera-Vargas, P., \& Miño-Puigcercós, R (2019). Moving beyond the predictable failure of EdTech initiatives. Learning, Media and Technology, DOI: 10.1080/17439884.2019.1666873.

Sawant, V. (n.d.). Neurohacking - Legal and Ethical Issues. Retrieved from https://www.academia.edu/40103356/Neurohacking_-Legal_and_Ethical_Issues

Shallis, M. (1986) El ídolo de silicio. Barcelona: Salvat.

Strauss, V. (2018). Bill Gates spent hundreds of millions of dollars to improve teaching. New report says it was a bust. The Washington Post. Retrieved from https://www.washingtonpost.com/news/answersheet/wp/2018/06/29/bill-gates-spent-hundreds-of-millions-of-dollars-to-improve-teaching-newreport-says-it-was-a-bust/

The Guardian (n.d.a.). Fresh Cambridge Analytica leak 'shows global manipulation is out of control'. Retrieved from https://www.theguardian.com/uk-news/2020/jan/04/cambridge-analytica-data-leak-globalelection-manipulation

The Guardian (n.d.b.). Leaked: Cambridge Analytica's blueprint for Trump victory. Retrieved from https://www.theguardian.com/uk-news/2018/mar/23/leaked-cambridge-analyticas-blueprint-fortrump-victory

Thompson, G. (2017). Computer adaptive testing, big data and algorithmic approaches to education. British Journal of Sociology of Education, (38)6, 827-840, DOI: 10.1080/01425692.2016.1158640

Torres, A. (2019, April 6). Empantallados: la "adicción sin sustancia" que empieza a los 14 años. El País. Retrieved from https://elpais.com/sociedad/2019/03/23/actualidad/1553363424_494890.html

Twenge, J. M. (2017). IGen: Why Today's Super-Connected Kids Are Growing Up Less Rebellious, More Tolerant, Less Happy--and Completely Unprepared for Adulthood--and What That Means for the Rest of Us. New York: Simon and Schuster.

Uncapher, M. R., Thieu, K., \& Wagner, A. D. (2016). Media multitasking and memory: Differences in working memory and long-term memory. Psychon Bull Rev. 23(2), 483-90. doi: 10.3758/s13423-015-0907-3.

Warzel, Ch. (2019, July 2). Welcome to the K-12 Surveillance State. Is tech really the solution to student safety? New York Time. Retrieved from https://www.nytimes.com/2019/07/02/opinion/surveillancestate-schools. html?action $=$ click\&module $=$ Opinion\&pgtype $=$ Homepage

Weiser, M. (1991). The Computer for the 21st Century. Scientific American, 265(3). 94-104.

Weller, C. (2018, February 18). Silicon Valley parents are raising their kids tech-free - and it should be a red flag. Retrieved from https://www.businessinsider.com/silicon-valley-parents-raising-their-kids-techfree-red-flag-2018-2?IR=T

Williamson, B. (2017). Big Data in Education: The Digital Future of Learning, Policy and Practice. London: SAGE Publications.

Zajda, J. (2015). Second International Handbook on Globalisation, Education and Policy Research. Dordrecht: Springer Netherlands. 